\title{
Degradation of the Insecticides Thiamethoxam and Imidacloprid in Aqueous Solution as Promoted by an Innovative $\mathrm{Fe}^{\circ} / \mathrm{Fe}_{3} \mathrm{O}_{4}$ Composite
}

\author{
Ana P. F. M. de Urzedo, Clésia C. Nascentes* and Rodinei Augusti \\ Departamento de Química, Universidade Federal de Minas Gerais, 31270-901 Belo Horizonte-MG, Brazil
}

$\mathrm{O}$ desempenho do compósito $\mathrm{Fe}^{\mathrm{o}} / \mathrm{Fe}_{3} \mathrm{O}_{4}$ na degradação dos inseticidas Thiamethoxam e Imidacloprid em solução aquosa foi avaliado. Planejamentos fatoriais foram realizados para verificar a influência das variáveis: concentração de $\mathrm{H}_{2} \mathrm{O}_{2}, \mathrm{pH}$ da solução e massa de compósito, em tais processos de degradação. $\mathrm{O}$ pH da solução foi a variável mais importante; deste modo, níveis de degradação elevados (>90\%) foram obtidos exclusivamente em soluções ácidas (pH=2). O compósito foi altamente eficiente na degradação dos inseticidas tanto na presença quanto, inesperadamente, na ausência de $\mathrm{H}_{2} \mathrm{O}_{2}$. Estes resultados indicaram que o compósito apresentou um comportamento ambíguo, podendo atuar como um agente oxidante ou redutor.

The performance of an innovative $\mathrm{Fe}^{\mathrm{o}} / \mathrm{Fe}_{3} \mathrm{O}_{4}$ composite to degrade the insecticides Thiamethoxam and Imidacloprid in aqueous solution was evaluated. Factorial designs were built to investigate the influence of a number of crucial variables on such degradation processes: $\mathrm{H}_{2} \mathrm{O}_{2}$ concentration, solution $\mathrm{pH}$, and composite mass. The solution $\mathrm{pH}$ was the most influential variable; hence, significant degradation rates (>90\%) was accomplished exclusively in acidic solutions $(\mathrm{pH}=2)$. In addition, the composite was highly efficient in promoting the degradation of both insecticides either in the presence or unpredictably in the absence of $\mathrm{H}_{2} \mathrm{O}_{2}$. These results thus indicated that the composite possess a dual behavior, acting as either an oxidizing or a reducing agent.

Keywords: thiamethoxam, imidacloprid, degradation, $\mathrm{Fe}^{\mathrm{o}} / \mathrm{Fe}_{3} \mathrm{O}_{4}$ composite, factorial design

\section{Introduction}

Neonicotinoids, a relatively new class of insecticides so named due to their similarity in structure to nicotine, represent the most emergent class of insecticides since the advent of pyrethroids, with an estimate annual market share above $€ 600$ million. ${ }^{1}$ These insecticides are active against numerous sucking and biting insect pests, including aphides, whiteflies, beetles and some lepidoptera species. ${ }^{1-3}$

Imidacloprid and Thiamethoxam (Figure 1), two of the most used neonicotinoid insecticides, are among the most profitable pesticides worldwide. However, their characteristic properties, such as low soil sorption and high leaching capability, make them potential contaminants of surface and underground waters. ${ }^{4}$

Over the past few years, zero-valent iron has gained popularity as an optional treatment for the remediation of more complex anthropogenic chemicals due to its low cost, efficiency and non-toxicity. Zero-valent iron is able to

*e-mail: clesia@qui.ufmg.br promote the degradation of a number of target compounds via the reduction of their critical functional groups. For instance, the reductive dechlorination of pesticides by $\mathrm{Fe}^{\circ}$ has been reported by Dombek et al. ${ }^{5}$ Despite of the most studies on the degradation of organic chemicals by zero-valent iron has focused on the reductive mechanisms, $\mathrm{Fe}^{\circ}$ particles can also be used to initiate oxidative reactions. For instance, Joo et al. ${ }^{6}$ verified the formation of hydroxyl radicals, potent oxidizing species used to degrade target organic molecules, ${ }^{7-12}$ via the direct reaction of $\mathrm{Fe}^{\circ}$ with $\mathrm{H}_{2} \mathrm{O}_{2}$ in acidic medium via a Fentom-like mechanism (equations 1 and 2):

$\mathrm{Fe}^{\mathrm{o}}+2 \mathrm{H}^{+} \rightarrow \mathrm{Fe}^{2+}+\mathrm{H}_{2}$
$\mathrm{Fe}^{2+}+\mathrm{H}_{2} \mathrm{O}_{2} \rightarrow \mathrm{Fe}^{3+}+\mathrm{HO}^{\circ}+\mathrm{HO}^{-}$

More recently, a novel $\mathrm{Fe}^{\mathrm{o}} / \mathrm{Fe}_{3} \mathrm{O}_{4}$ composite, in the presence of $\mathrm{H}_{2} \mathrm{O}_{2}$, has been reported as an efficient system to be potentially applied in the degradation of a number of organic molecules in aqueous solution. ${ }^{13,14}$ The authors proposed that the hydroxyl radicals could be formed via the reaction of $\mathrm{H}_{2} \mathrm{O}_{2}$ and $\mathrm{Fe}^{2+}\left(\mathrm{Fe}^{2+}\right.$ was suggested to be 


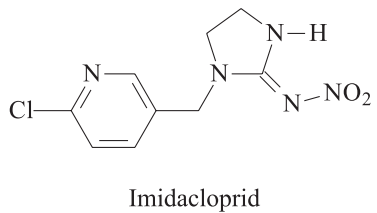

IUPAC name: 1-(6-chloro-3-pyridylmethyl)-N-nitroimidazolidin-2-ylideneamine

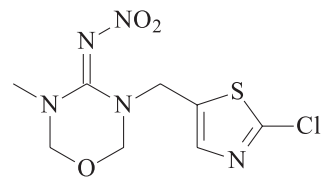

Thiamethoxam

IUPAC name: 3-(2-chloro-1,3-thiazol-5-ylmethyl)-5-methyl-1,3,5-oxadiazinan-4-ylidene(nitro)amine

Figure 1. Chemical structures of the neonicotinoid insecticides Imidacloprid and Thiamethoxam.

generated by means of a direct interaction between $\mathrm{Fe}^{\mathrm{o}}$ and $\mathrm{Fe}^{3+}$ at the surface of the composite) in a Fenton-like mechanism (equation 2). ${ }^{13}$

Multivariate analysis has become an important tool for obtaining valuable and statistically significant models of a phenomenon by performing a minimum set of wellselected experiments. With a determined number of assays, information can be obtained regarding the importance of each variable and their interaction effects..$^{15}$ In this work, factorial designs are employed to investigate the degradation of the pesticides Imidacloprid and Thiamethoxam promoted by a recently-reported $\mathrm{Fe}^{\circ} / \mathrm{Fe}_{3} \mathrm{O}_{4}$ composite ${ }^{14}$ in aqueous solution aiming to gain new insights on this system. The influence of three major parameters, i.e. $\mathrm{H}_{2} \mathrm{O}_{2}$ concentration, solution $\mathrm{pH}$, and amount of the $\mathrm{Fe}^{\circ} / \mathrm{Fe}_{3} \mathrm{O}_{4}$ composite, is thus detailed investigated.

\section{Experimental}

\section{Chemicals}

All the chemicals were used as received. The insecticides Thiamethoxam and Imidacloprid were purchased from Sigma-Aldrich (Milwaukee, WI, USA), whereas $\mathrm{H}_{2} \mathrm{O}_{2} 32 \%$ $(\mathrm{m} / \mathrm{m})$ and $\mathrm{HCl} 37 \%(\mathrm{~m} / \mathrm{m})$ were acquired from Merck (Whitehouse Station, NJ, USA). The $\mathrm{Fe}^{\circ} / \mathrm{Fe}_{3} \mathrm{O}_{4}$ composite was prepared accordingly to a previously-described procedure by Moura et al. ${ }^{14}$ Doubly-distilled water was used to prepare the solutions in all the experiments.

\section{Experimental design}

Two factorial designs were built to determine the optimal conditions for the degradation of both insecticides. The influence of a number of variables (hydrogen peroxide concentration, solution $\mathrm{pH}$, and composite mass), as well as their interactions, was thus established. Minimum and maximum levels for each variable were chosen based on previous (and unpublished) results from our laboratory.

For the first experimental design, a $2^{2}$ factorial with 4 experiments, the following variables were evaluated: $\mathrm{H}_{2} \mathrm{O}_{2}$ concentration $\left(0.0\right.$ or $\left.0.06 \mathrm{~mol} \mathrm{~L}^{-1}\right)$ and solution $\mathrm{pH}(2$ or 5$)$. In the second design, a $2^{3}$ factorial with 8 experiments, a new variable was included: the $\mathrm{Fe}^{\circ} / \mathrm{Fe}_{3} \mathrm{O}_{4}$ composite mass. Hence, the experiments were conducted by using the following levels for each variable: $\mathrm{H}_{2} \mathrm{O}_{2}$ concentration, 0.00 or $0.06 \mathrm{~mol} \mathrm{~L}^{-1}$; solution $\mathrm{pH} 2$ or 5 ; composite mass, 1.0 or $10.0 \mathrm{mg}$. The experiments, carried out in a random order, were performed in duplicates. A confidence interval of $95 \%$ was used to determine the most significant effects. The calculations were carried out by using the Statgraphics software.

\section{Reactions promoted by the $\mathrm{Fe}^{\circ} / \mathrm{Fe}_{3} \mathrm{O}_{4}$ composite}

In a typical run, an aqueous solution containing $\mathrm{H}_{2} \mathrm{O}_{2}$ (0.00 or $\left.0.06 \mathrm{~mol} \mathrm{~L}^{-1}\right)$ and Imidacloprid $\left(20 \mathrm{~mL} ; 35 \mathrm{mg} \mathrm{L}^{-1}\right)$ or Thiamethoxam ( $\left.20 \mathrm{~mL} ; 50 \mathrm{mg} \mathrm{L}^{-1}\right)$ was prepared. The solution $\mathrm{pH}$ was adjusted to 2 or 5 by slowly dropping $\mathrm{HCl}$ $\left(1 \mathrm{~mol} \mathrm{~L}^{-1}\right)$ and then a specified amount $(1.0$ or $10.0 \mathrm{mg}$ ) of the $\mathrm{Fe}^{\circ} / \mathrm{Fe}_{3} \mathrm{O}_{4}$ composite added. The resulting suspension was maintained under constant and vigorous stirring for $30 \mathrm{~min}$. Aliquots $(5.0 \mathrm{~mL})$ were taken and filtered by using a Millipore (Milford, MA, USA) filter $(0.45 \mu \mathrm{m})$. All the samples were kept protected from light in a refrigerator at $4{ }^{\circ} \mathrm{C}$ prior to the HPLC analysis.

\section{Analytical methods}

HPLC analyses were carried out in a SPD-10A (Shimadzu, Kyoto, Japan) instrument using a Supelcosil C18 
column $(250 \mathrm{~mm}$ length $\times 4.6 \mathrm{~mm}$ i.d., $5 \mu \mathrm{m}$ particle size $)$. The following operating conditions were employed: isocratic elution of $\mathrm{MeOH} / \mathrm{H}_{2} \mathrm{O}(1: 9)$, flow rate of $1 \mathrm{~mL} \mathrm{~min}^{-1}$, injection volume of $20 \mu \mathrm{L}$, and UV-Vis detector set up at 270 and $254 \mathrm{~nm}$ for Imidacloprid and Thiamethoxam, respectively. The degradation rate as a function of reaction time was calculated based on the peak area obtained upon the injection of the initial solution of each insecticide (Imidacloprid $35 \mathrm{mg} \mathrm{L}^{-1}$ and Thiamethoxam $50 \mathrm{mg} \mathrm{L}^{-1}$ ), for which a relative intensity of $100 \%$ ( $0 \%$ degradation) was attributed.

\section{Results and Discussion}

To verify the influence of $\mathrm{H}_{2} \mathrm{O}_{2}$ and $\mathrm{pH}$ on the degradation of the insecticides Thiamethoxam and Imidacloprid in aqueous solution, a set of experiments were initially conducted in the absence of the $\mathrm{Fe}^{\mathrm{o}} / \mathrm{Fe}_{3} \mathrm{O}_{4}$ composite. Table 1 displays the $2^{2}$ factorial design built and shows the degradation yields achieved for each insecticide after a reaction time of 30 minutes.

Table 1. Factorial design $\left(2^{2}\right)$ showing the degradation yields of the insecticides Imidacloprid and Thiamethoxam in aqueous solution after a reaction time of 30 minutes. The inferior (-) and superior (+) levels of each variable $\left(\mathrm{H}_{2} \mathrm{O}_{2}\right.$ concentration and solution $\left.\mathrm{pH}\right)$ are indicated. All the experiments were performed in duplicate

\begin{tabular}{ccccc}
\hline \multicolumn{2}{l}{ Variable values (codified levels) } & & \multicolumn{2}{c}{ Degradation / (\%) $)^{\mathrm{a}}$} \\
\cline { 1 - 2 } \cline { 5 - 5 }$\left[\mathrm{H}_{2} \mathrm{O}_{2}\right] /\left(\mathrm{mol} \mathrm{L}^{-1}\right)$ & $\mathrm{pH}$ & & Thiamethoxam & Imidacloprid \\
\hline $0.00(-)$ & $2(-)$ & & $1.4 ; 1.0$ & $6.4 ; 7.0$ \\
$0.06(+)$ & $2(-)$ & & $3.2 ; 3.0$ & $24.2 ; 23.0$ \\
$0.00(-)$ & $5(+)$ & & $1.0 ; 2.0$ & $0.0 ; 0.0$ \\
$0.06(+)$ & $5(+)$ & & $4.9 ; 4.0$ & $9.9 ; 8.0$ \\
\hline
\end{tabular}

Table 1 reveals that under these experimental conditions the degradation of both insecticides was quite modest. For instance, the best result was achieved when Imidacloprid was degraded by $\mathrm{H}_{2} \mathrm{O}_{2}$ at a concentration of $0.06 \mathrm{~mol} \mathrm{~L}^{-1}$ and $\mathrm{pH} 2$, with an average degradation yield of $23.6 \%$ after a reaction time of 30 minutes. On the other hand, Table 2 shows that only $\mathrm{H}_{2} \mathrm{O}_{2}$ concentration has a statistically significant effect (although quite small) on the degradation of Thiamethoxam. For Imidacloprid, however, higher effects of both variables could be detected. Hence, the decrease in the solution $\mathrm{pH}$ from 5 to 2 and the elevation of the $\mathrm{H}_{2} \mathrm{O}_{2}$ concentration from 0.00 to $0.06 \mathrm{~mol} \mathrm{~L}^{-1}$ promoted an average increase in the Imidacloprid degradation of $10.7 \%$ and $12.9 \%$, respectively. In addition, contrarily to that observed for Thiamethoxam, a noticeable effect from the interaction between such variables on the degradation of Imidacloprid could be noticed (Table 2). These results thus indicate that both insecticides seem not to be extensively degraded neither by the influence of an acidic medium nor by the presence of $\mathrm{H}_{2} \mathrm{O}_{2}$. In addition, Imidacloprid seems to be slightly more susceptible to degradation in aqueous solution than Thiamethoxam, at least under the conditions employed herein.

Table 2. The effects of the variables $\left[\mathrm{H}_{2} \mathrm{O}_{2}\right]$ and $\mathrm{pH}$ and their interactions on the degradation of Thiamethoxam and Imidacloprid

\begin{tabular}{lcc}
\hline Variable & \multicolumn{2}{c}{ Effect / $(\%)^{\mathrm{a}}$} \\
\cline { 2 - 3 } & Thiamethoxam & Imidacloprid \\
\hline$\left[\mathrm{H}_{2} \mathrm{O}_{2}\right]$ & $2.4 \pm 1$ & $12.9 \pm 1.6$ \\
$\mathrm{pH}$ & $0.8 \pm 1$ & $-10.7 \pm 1.6$ \\
{$\left[\mathrm{H}_{2} \mathrm{O}_{2}\right] / \mathrm{pH}^{\mathrm{b}}$} & $0.5 \pm 1$ & $-4.0 \pm 1.6$ \\
\hline
\end{tabular}

${ }^{\mathrm{a}}$ The error range represents a $95 \%$ confidence interval; ${ }^{\text {Interaction }}$ between both variables.

To verify the influence of the $\mathrm{Fe}^{\mathrm{o}} / \mathrm{Fe}_{3} \mathrm{O}_{4}$ composite on the degradation of Thiamethoxam and Imidacloprid, a second factorial design was built and the results are displayed in Table 3. These results indicate that quite high degradation yields $(>90 \%)$ for both insecticides were achieved when the $\mathrm{Fe}^{\mathrm{o}} / \mathrm{Fe}_{3} \mathrm{O}_{4}$ composite was employed (assays 1, 4, and 7). Note that in all these assays the solution $\mathrm{pH}$ was 2 thus indicating that this variable plays an important role in this process. The $\mathrm{pH}$ effect can be better visualized in the Pareto chart shown in Figure 2 (a Pareto chart indicates the magnitude and the significance of each effect (single variables and double/triple interactions) and contains a reference line so that any effect that goes beyond this line is potentially important).$^{16}$ Figure 2 thus indicates that by decreasing the $\mathrm{pH}$ from 5 (assays 2, 5, 6 , and 8 , for which a very low degradation yields were accomplished) to 2, an average increase of ca. $71 \%$ and $77 \%$ in the degradation yields of Thiamethoxam and Imidacloprid was achieved, respectively. The negative effect of $\mathrm{pH}$ as displayed in Figure 2 is thus caused by the decrease in the degradation yield of both insecticides as the reaction $\mathrm{pH}$ is shifted from 2 (arbitrarily attributed to be the negative or inferior level) to 5 (the positive or superior level. At higher $\mathrm{pH}$ the formation of insoluble ferrous oxides and hydroxides possibly reduces the amount of available $\mathrm{Fe}^{2+}$ in solution thus preventing the formation of hydroxyl radicals and, ultimately, the degradation of the target compounds via a Fentom-like mechanism (equation 2). Recent reports have demonstrated that the solution $\mathrm{pH}$ is of vital importance for the effectiveness of a number of heterogeneous degradation processes. ${ }^{5,17,18}$ Figure 2 also shows that the other variables $\left(\left[\mathrm{H}_{2} \mathrm{O}_{2}\right]\right.$ and $\left.\mathrm{m}\left(\mathrm{Fe}^{\circ} / \mathrm{Fe}_{3} \mathrm{O}_{4}\right)\right)$ as well the double and triple interactions appear to have 
Table 3. Factorial design $\left(2^{3}\right)$ showing the yields of the degradation of the insecticides Thiamethoxam and Imidacloprid in aqueous solution after a reaction time of 30 minutes. All the experiments were performed in duplicate. The symbols (+) and (-) indicate the highest and the lowest levels used for each variable, respectively

\begin{tabular}{|c|c|c|c|c|c|}
\hline \multirow[t]{2}{*}{ Assay } & \multicolumn{3}{|c|}{ Variable levels (codified values) } & \multicolumn{2}{|c|}{ Degradation / (\%) } \\
\hline & {$\left[\mathrm{H}_{2} \mathrm{O}_{2}\right] /\left(\mathrm{mol} \mathrm{L}^{-1}\right)$} & $\mathrm{pH}$ & $\mathrm{m}\left(\mathrm{Fe}^{\mathrm{o}} / \mathrm{Fe}_{3} \mathrm{O}_{4}\right) / \mathrm{mg}$ & Thiamethoxam & Imidacloprid \\
\hline 1 & $0.06(+)$ & $2(-)$ & $1(-)$ & $100.0 ; 99.0$ & $100.0 ; 98.0$ \\
\hline 2 & $0.00(-)$ & $5(+)$ & $10(+)$ & $2.4 ; 2.0$ & $1.6 ; 2.0$ \\
\hline 3 & $0.00(-)$ & $2(-)$ & $1(-)$ & $10.5 ; 15.0$ & $33.0 ; 32.0$ \\
\hline 4 & $0.06(+)$ & $2(-)$ & $10(+)$ & $100.0 ; 98.0$ & $100.0 ; 98.0$ \\
\hline 5 & $0.06(+)$ & $5(+)$ & $1(-)$ & $5.2 ; 6.0$ & $6.5 ; 5.0$ \\
\hline 6 & $0.00(-)$ & $5(+)$ & $1(-)$ & $0.0 ; 3.0$ & $8.0 ; 7.0$ \\
\hline 7 & $0.00(-)$ & $2(-)$ & $10(+)$ & $88.0 ; 87.0$ & $98.0 ; 99.0$ \\
\hline 8 & $0.06(+)$ & $5(+)$ & $10(+)$ & $5.8 ; 6.0$ & $7.0 ; 6.0$ \\
\hline
\end{tabular}

a smaller effect (but still statistically significant) on the degradation of both insecticides.

The results from assay $7\left(\left[\mathrm{H}_{2} \mathrm{O}_{2}\right]=0 \mathrm{~mol} \mathrm{~L}^{-1}\right.$; $\left.\mathrm{pH}=2 ; \mathrm{m}\left(\mathrm{Fe}^{\mathrm{o}} / \mathrm{Fe}_{3} \mathrm{O}_{4}\right)=10 \mathrm{mg}\right)$ indicated that the $\mathrm{Fe}^{\mathrm{O}} / \mathrm{Fe}_{3} \mathrm{O}_{4}$ composite was highly efficient in promoting the degradation of both insecticides even in the absence of $\mathrm{H}_{2} \mathrm{O}_{2}$ with average degradation yields of $87.5 \%$ and $98.5 \%$ for Thiamethoxam and Imidacloprid, respectively. In this case, a reductive degradation of both insecticides, supposedly via an initial electron transfer from the superficial $\mathrm{Fe}^{\circ}$ to the target molecules, was proposed to take place. In fact, the use of a smaller mass of the $\mathrm{Fe}^{\circ} / \mathrm{Fe}_{3} \mathrm{O}_{4}$ composite (assay 3: $\left.\left[\mathrm{H}_{2} \mathrm{O}_{2}\right]=0 \mathrm{~mol} \mathrm{~L}-1 ; \mathrm{pH}=2 ; \mathrm{m}\left(\mathrm{Fe}^{\mathrm{o}} / \mathrm{Fe}_{3} \mathrm{O}_{4}\right)=1 \mathrm{mg}\right)$ caused a proportional decrease in the degradation yields for both insecticides (averages of $12.8 \%$ and 32.5 for Thiamethoxam and Imidacloprid, respectively).

Conversely, in assay $1\left(\left[\mathrm{H}_{2} \mathrm{O}_{2}\right]=0.06 \mathrm{~mol} \mathrm{~L}^{-1} ; \mathrm{pH}=2\right.$; $\left.\mathrm{m}\left(\mathrm{Fe}^{\mathrm{o}} / \mathrm{Fe}_{3} \mathrm{O}_{4}\right)=1 \mathrm{mg}\right)$, where $\left[\mathrm{H}_{2} \mathrm{O}_{2}\right]$ and $\mathrm{m}\left(\mathrm{Fe}^{\circ} / \mathrm{Fe}_{3} \mathrm{O}_{4}\right)$ were employed at their highest and lowest levels, respectively, an essentially complete degradation of both insecticides

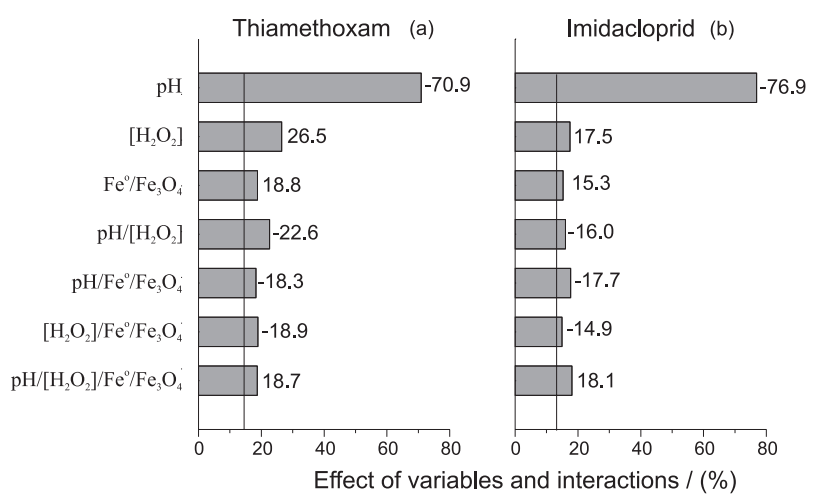

Figure 2. The Pareto chart for the degradation of: (a) Thiamethoxam; and (b) Imidacloprid. These plots were built based on the data displayed in Table 3. was achieved. This result strongly suggests that the $\mathrm{Fe}^{\text {\% }}$ $\mathrm{Fe}_{3} \mathrm{O}_{4}$ composite, in the presence of an excess of $\mathrm{H}_{2} \mathrm{O}_{2}$ and at $\mathrm{pH} 2$, can possibly promote the oxidation of both target molecules via an initial attack of in situ-generated hydroxyl radicals, as stated in equation 2 . Finally, the experimental array utilized in assay $4\left(\mathrm{pH}=2 ;\left[\mathrm{H}_{2} \mathrm{O}_{2}\right]\right.$ and $\mathrm{m}\left(\mathrm{Fe}^{\mathrm{o}} / \mathrm{Fe}_{3} \mathrm{O}_{4}\right)$ at their maximum levels) once more caused the almost complete degradation of both insecticides. Under these conditions, in which the $\left[\mathrm{H}_{2} \mathrm{O}_{2}\right] / \mathrm{m}\left(\mathrm{Fe}^{\mathrm{o}} / \mathrm{Fe}_{3} \mathrm{O}_{4}\right)$ relationship (nominally 0.006 ) is not as high as that verified in assay $1\left(\left[\mathrm{H}_{2} \mathrm{O}_{2}\right] / \mathrm{m}\left(\mathrm{Fe}^{\mathrm{o}} / \mathrm{Fe}_{3} \mathrm{O}_{4}\right)=0.06\right)$ and not as low as that found in assay $7\left(\left[\mathrm{H}_{2} \mathrm{O}_{2}\right] / \mathrm{m}\left(\mathrm{Fe}^{\mathrm{o}} / \mathrm{Fe}_{3} \mathrm{O}_{4}\right)=0\right)$, one can plausibly infer that both substrates could be concurrently degraded via either a reduction promoted by particles of zero-valent iron at the composite surface or an oxidation caused by hydroxyl radicals (equation 2). Similar findings were previously reported by Boussahel and coworkers whose suggested that the degradation of DDT (an obsolete chlorinated pesticide) in acidic aqueous solution by zerovalent iron and in the presence of $\mathrm{H}_{2} \mathrm{O}_{2}$ could similarly occur via a reductive (electron transfer from the surface iron to the chlorine atoms) or an oxidative (hydroxyl radicals attack) process. ${ }^{19}$

\section{Mathematical modeling}

To predict the results from experiments conducted under somewhat distinct conditions than the ones employed herein and even to achieve an optimized response, the data displayed in Table 3 were compiled to generate mathematical equations that correlate the Thiamethoxan (TDY) and Imidacloprid (IDY) degradation yields (\%) with the variables $\left[\mathrm{H}_{2} \mathrm{O}_{2}\right]$, $\mathrm{pH}$, and $\mathrm{m}\left(\mathrm{Fe}^{\mathrm{o}} / \mathrm{Fe}_{3} \mathrm{O}_{4}\right)$. The resulting mathematical models for TDY and IDY are displayed in equations 3 and 4, respectively: 

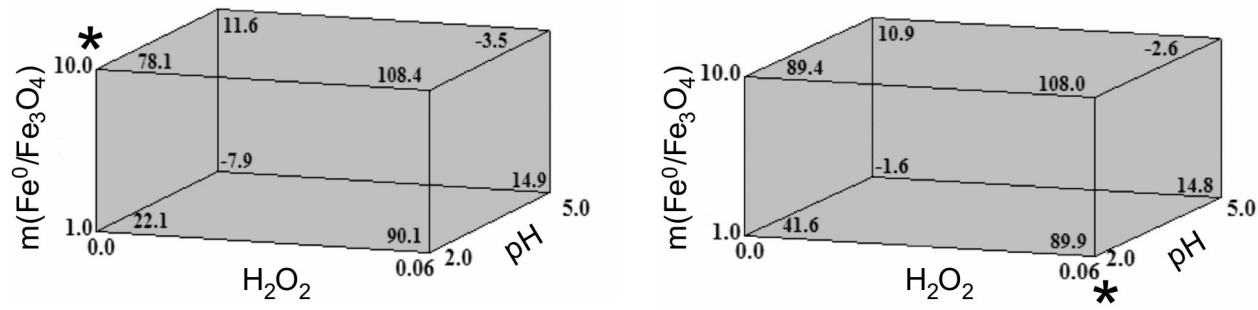

Figure 3. Cube plots showing the predicted degradation yields (responses) for: (a) Thiamethoxan and (b) Imidacloprid. The responses were calculated by using equations 3 and 4, respectively. For instance, in the labeled vertex of Figure $3 \mathrm{a}$ the experimental conditions are: $\left[\mathrm{H}_{2} \mathrm{O}_{2}\right]=0.00 \mathrm{~mol} \mathrm{~L}{ }^{-1} ; \mathrm{pH}^{2}=2$; $\mathrm{m}\left(\mathrm{Fe}^{\circ} / \mathrm{Fe}_{3} \mathrm{O}_{4}\right)=10.0 \mathrm{mg}$ whereas the predicted degradation yield is calculated to be $78.1 \%$ /

$\mathrm{TDY}=33.1+1706.5\left[\mathrm{H}_{2} \mathrm{O}_{2}\right]-8.6 \mathrm{pH}+8.9 \mathrm{~m}\left(\mathrm{Fe}^{\mathrm{o}} / \mathrm{Fe}_{3} \mathrm{O}_{4}\right)$ $-251.3\left[\mathrm{H}_{2} \mathrm{O}_{2}\right] \mathrm{pH}-70.1\left[\mathrm{H}_{2} \mathrm{O}_{2}\right] \mathrm{m}\left(\mathrm{Fe}^{\mathrm{o}} / \mathrm{Fe}_{3} \mathrm{O}_{4}\right)-1.4 \mathrm{pH}$ $\mathrm{m}\left(\mathrm{Fe}^{\mathrm{o}} / \mathrm{Fe}_{3} \mathrm{O}_{4}\right)$

IDY $=62.4+1217.4\left[\mathrm{H}_{2} \mathrm{O}_{2}\right]-13.1 \mathrm{pH}+8.0 \mathrm{~m}\left(\mathrm{Fe}^{\mathrm{o}} / \mathrm{Fe}_{3} \mathrm{O}_{4}\right)$ $-177.9\left[\mathrm{H}_{2} \mathrm{O}_{2}\right] \mathrm{pH}-55.1\left[\mathrm{H}_{2} \mathrm{O}_{2}\right] \mathrm{m}\left(\mathrm{Fe}^{\circ} / \mathrm{Fe}_{3} \mathrm{O}_{4}\right)-1.3 \mathrm{pH}$ $\mathrm{m}\left(\mathrm{Fe}^{\mathrm{O}} / \mathrm{Fe}_{3} \mathrm{O}_{4}\right)$

These simple linear models, which do not include quadratic terms or even the third interaction factor (i.e. $\left[\mathrm{H}_{2} \mathrm{O}_{2}\right] / \mathrm{pH} / \mathrm{m}\left(\mathrm{Fe}^{\mathrm{o}} / \mathrm{Fe}_{3} \mathrm{O}_{4}\right)$, were able to explain more than $90 \%$ of the total experimental variance. Note also that, consistent with the results verified in the Pareto chart (Figure 2), all the coefficients of the second order interactions possess negative values thus indicating the incidence of antagonistic effects among the variables. Consequently, each variable contributes to counteract the effect of another one.

Figure 3 shows the cube plots with the responses (degradation yields) predicted by the simple linear models as described in equations 3 and 4. A good agreement between the experimental and calculated responses could thus be observed in all the eight experimental conditions evaluated herein. For instance, the average degradation yield observed for Thiamethoxam in assay $7\left(\left[\mathrm{H}_{2} \mathrm{O}_{2}\right]=\right.$ $0.00 \mathrm{~mol} \mathrm{~L}^{-1} ; \mathrm{pH}=2 ; \mathrm{m}\left(\mathrm{Fe}^{\circ} / \mathrm{Fe}_{3} \mathrm{O}_{4}\right)=10.0 \mathrm{mg}$ ) was found to be $87.5 \%$ (Table 3 ) against a predicted value of $78.1 \%$ (Figure 3a, labeled vertex). Similarly, the average degradation yield of Imidacloprid in assay $1\left(\left[\mathrm{H}_{2} \mathrm{O}_{2}\right]=0.06 \mathrm{~mol} \mathrm{~L}^{-1}\right.$; $\left.\mathrm{pH}=2 ; \mathrm{m}\left(\mathrm{Fe}^{\circ} / \mathrm{Fe}_{3} \mathrm{O}_{4}\right)=1.0 \mathrm{mg}\right)$ was observed to be $99 \%$ (Table 3) whereas the predicted value by equation 4 was determined to be $89.9 \%$ (Figure 3b, labeled vertex).

\section{Conclusions}

The results reported herein clearly show that the $\mathrm{Fe} / \mathrm{Fe}_{3} \mathrm{O}_{4}$ composite is highly efficient in promoting the degradation of the insecticides Thiamethoxam and Imidacloprid in acidic aqueous solution. These findings also indicate that the $\mathrm{Fe}^{\circ} / \mathrm{Fe}_{3} \mathrm{O}_{4}$ composite can behave as a reducing or an oxidizing agent depending on the reaction set up (absence or presence of $\mathrm{H}_{2} \mathrm{O}_{2}$, respectively). Studies are underway in our laboratory to identify the products formed upon the degradation of both insecticides under these assorted conditions.

\section{Acknowledgments}

The authors thank the Brazilian Agencies FAPEMIG and CNPq for financial support. We also acknowledge Prof. Rochel Montero Lago and Prof. Maria Helena Araújo (from the Laboratory of Environmental Catalyst, Chemistry Department, Federal University of Minas Gerais) who kindly supplied us with a sufficient amount of the $\mathrm{Fe}^{\mathrm{o}} / \mathrm{Fe}_{3} \mathrm{O}_{4}$ composite to perform all the tests.

\section{References}

1. Tomizawa, M.; Casida, J. E.; Annu. Rev. Pharmacol. Toxicol. 2005, 45, 247.

2. Maienfisch, P.; Angst, M.; Brandl, F.; Fischer, W.; Hofer, D.; Kayser, H.; Kobel, W.; Rindlisbacher, A.; Senn, R.; Steinemann, A.; Widmer, H.; Pest Manag. Sci. 2001, 57, 906.

3. Suchail, S.; Guez, D.; Belzunces, L. P.; Environ. Toxicol. Chem. 2000, 19, 1901 .

4. Di Muccio, A.; Fidente, P.; Barbini, D. A.; Dommarco, R.; Seccia, S.; Morrica, P.; J. Chromatogr. A 2006, 1108, 1.

5. Dombek, T.; Dolan, E.; Schultz, J.; Klarup, D.; Environ. Pollut. 2001, 111, 21.

6. Joo, S. H.; Feitz, A. J.; Waite, T. D.; Environ. Sci. Technol. 2004, $38,2242$.

7. Augusti, R.; Dias, A. O.; Rocha, L. L.; Lago, R. M.; J. Phys. Chem. A 1998, 102, 10723.

8. Dalmazio, I.; Alves, T. M. A.; Augusti, R.; J. Braz. Chem. Soc. 2008, 19, 81.

9. Dalmazio, I.; de Urzedo, A. P. F. M.; Alves, T. M. A.; Catharino, R. R.; Eberlin, M. N.; Nascentes, C. C.; Augusti, R.; J. Mass Spectrom. 2007, 42, 1273. 
10. Dalmazio, I.; Santos, L. S.; Lopes, R. P.; Eberlin, M. N.; Augusti, R.; Environ. Sci. Technol. 2005, 39, 5982.

11. de Morais, J. L.; Zamora, P. P.; J. Hazard. Mater. 2005, 123, 181.

12. Santos, L. S.; Dalmazio, I.; Eberlin, M. N.; Claeys, M.; Augusti, R.; Rapid Commun. Mass Spectrom. 2006, 20, 2104.

13. Moura, F. C. C.; Araujo, M. H.; Dalmazio, I.; Alves, T. M. A.; Santos, L. S.; Eberlin, M. N.; Augusti, R.; Lago, R. M.; Rapid Commun. Mass Spectrom. 2006, 20, 1859.

14. Moura, F. C. C.; Oliveira, G. C.; Araujo, M. H.; Ardisson, J. D.; Macedo, W. A. A.; Lago, R. M.; Appl. Catal. A 2006, 307, 195.
15. Perez, M.; Torrades, F.; Peral, J.; Lizama, C.; Bravo, C.; Casas, S.; Freer, J.; Mansilla, H. D.; Appl. Catal. B 2001, 33, 89.

16. Mosteo, R.; Ormad, P.; Mozas, E.; Sarasa, J.; Ovelleiro, J. L.; Water Res. 2006, 40, 1561.

17. Johnson, T. L.; Scherer, M. M.; Tratnyek, P. G.; Environ. Sci. Technol. 1996, 30, 2634.

18. Su, C. M.; Puls, R. W.; Environ. Sci. Technol. 1999, 33, 163.

19. Boussahel, R.; Harik, D.; Mammar, M.; Lamara-Mohamedl, S.; Desalination 2007, 206, 369.

Received: March 17, 2008

Web Release Date: October 31, 2008 